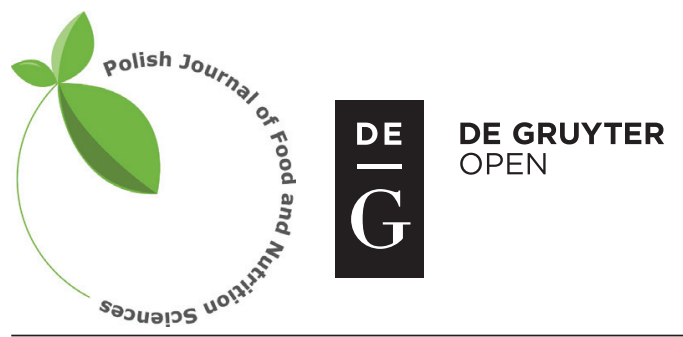

Pol. J. Food Nutr. Sci., 2016, Vol. 66, No. 4, pp. 253-260

DOI: $10.1515 /$ pjfns-2016-0022 http://journal.pan.olsztyn.pl

Original article

Section: Food Chemistry

\title{
Antioxidant Potential and Phenolic Compounds of Some Widely Consumed Turkish White Bean (Phaseolus vulgaris L.) Varieties
}

\author{
Hakime Hülya Orak ${ }^{1 *}$, Magdalena Karamać2 , Adnan Orak ${ }^{3}$, Ryszard Amarowicz ${ }^{2}$ \\ ${ }^{1}$ Department of Food Technology, Vocational School of Technical Sciences, Namik Kemal University, 59030 Tekirdağ, Turkey \\ ${ }^{2}$ Department of Chemical and Physical Properties of Food, Institute of Animal Reproduction and Food Research, \\ Polish Academy of Sciences, Tuwima 10, 10-748 Olsztyn, Poland \\ ${ }^{3}$ Department of Field Crops, Faculty of Agriculture, Namik Kemal University, 59030 Tekirdă̆, Turkey
}

Key words: white bean, phenolic compounds, antioxidant activity, FRAP, ABTS, $\beta$-carotene-linoleic acid emulsion

The antioxidant potential and phenolic compounds content were investigated in ten white bean varieties widely consumed in Turkey. Total phenolic contents of seeds varied between 0.33 and $0.63 \mathrm{mg} \mathrm{GAE} / \mathrm{g}$. The Trolox Equivalent Antioxidant Capacity (TEAC) determined by the ABTS assay and the Ferric-Reducing Antioxidant Power (FRAP) of bean varieties ranged from 3.50 to $5.17 \mu$ mol Trolox/g seed and from 7.99 to $11.20 \mu \mathrm{mol} \mathrm{Fe}{ }^{2+} / \mathrm{g}$ seed, respectively. Strong correlations were found between total phenolic content and FRAP $(r=0.850)$ and between TEAC and FRAP $(r=0.734)$. The antioxidant activity was investigated in a $\beta$-carotene-linoleic acid model system, as well. Differences in the inhibition of emulsion oxidation by extracts of white bean varieties were slight. The RP-HPLC fingerprint analysis of extracts showed the presence of five dominant phenolic compounds which were described as ferulic or caffeic acids derivatives. Four of them significantly contributed to reducing power and antiradical activity against $\mathrm{ABTS}^{*}+$ of extracts.

\section{INTRODUCTION}

In human nutrition, beans have been highlighted the have great importance in counteracting malnutrition problems owing to their nutritive value, i.e. high contents of protein and easily digestible starch. In recent years, more attention has been devoted to potential health benefits of beans stemming from the presence of bioactive constituents. In addition to nutritional components, some common beans (Phaseolus vulgaris $\mathrm{L}$.) are rich in several phytochemicals such as phenolic compounds especially including phenolic acids, flavonoids and tannins [Luthria \& Pastor-Corrales, 2006; Gulewicz et al., 2014; Agostini-Costa et al., 2015; Chen et al., 2015]. A number of articles have appeared in the literature that are focused on the antioxidant potential of common beans [Karamać et al., 2004; Xu et al., 2007; Amarowicz et al., 2008; Akond et al., 2011]. The consumption of bean has previously been associated with a reduced risk of cardiovascular diseases, diabetes and even certain types of cancer [Curran et al., 2012; Hayat et al., 2014]. Recently, Suárez-Martinez et al. [2016] reported the Phaseolus vulgaris as a nutraceutical source for human health with favourable effects against cancer because of the antimutagenic and antiproliferative properties of their phenolic compounds, lectins and protease inhibitors.

\footnotetext{
* Corresponding Author: E-mail: horak@nku.edu.tr (H.H. Orak)

Given the nutritional value and bioactive compounds profile of common beans, interest in their potential use for food formulations has aroused in some countries [Ramirez-Jiménez et al., 2014; Singh, 1999]. In recent years, bean has been gaining increasing attention as a functional or nutraceutical food capable of providing multiple health benefits [Boye et al., 2010; Câmara et al., 2013]. Taking into account the nutritional and economical aspects of common beans, fortification of corn with bean flour was investigated to determine the technical feasibility of increasing its nutritional value and it was reported that corn starch-bean extrudates had a strong potential to replace regular extruded snacks as a healthier option [Anton et al., 2009]. In a similar study, Gallegos-Infante et al. [2010] evaluated the effect of the addition of common bean flour to semolina on the cooking quality and total phenolic content of pasta.

Identification and quantification of phenolic compounds in beans is important for developing successful new value-added bean-based products for new market opportunities in the functional food and nutraceutical industry and currently there is great interest in examining the phytochemical composition of legumes [Amarowicz et al., 2008; Chen et al., 2015; Agostini-Costa et al., 2015]. On the other hand, some researchers reported that phenolic compounds content and antioxidant activities of bean seeds were significantly affected by cultivar [Oomah et al., 2005; Ramirez-Jiménez et al., 2014]. Moreno-Jiménez [2015] showed that variety had 
a strong impact on the profile of phytochemicals. Investigations carried out so far to determine the antioxidative potential and phenolics content in seeds of Phaseolus vulgaris L. have usually compared cultivars having different colours (red, black, brown, white bean, etc.). Little works are, however, available that would report on differences between various bean varieties with the same colour of seed coat. Therefore, the aim of the present study was to evaluate the antioxidant potential of ten different white bean varieties, to determine phenolic compounds content and to estimate which phenolic compounds present in the extract affect the antioxidant activity in polar and lipid systems.

\section{MATERIAL AND METHODS}

\section{Plant materials}

Ten varieties of seeds from white bean (Phaseolus vulgaris L.) were obtained from Field Crops Department, Agricultural Faculty of Namik Kemal University. These white bean varieties named as Göynük, Güngör, Noyanbey, Şehirali, Yunus 90, İspir, Göksun, Akman, Zülbiye and Karacaşehir originated from different regions of Turkey.

\section{Preparation of extracts}

Dried white bean seeds were milled with a laboratory mill and the powdered bean seeds were extracted with $80 \%$ methanol (v/v). To obtain crude extracts, a $15 \mathrm{~g}$ sample was mixed with $150 \mathrm{~mL}$ of solvent (1:10) and rinsed by using a shaking water bath (SW22, Julabo, USA) at $150 \mathrm{rpm}, 70^{\circ} \mathrm{C}$, and 15 min [Karamać et al., 2015]. The extractions were repeated three times, supernatants were combined and methanol was evaporated under vacuum using a rotary evaporator (Rotavapor R-200, Büchi Labortechnik, Switzerland). Remaining moisture was removed by lyophilisation for $\sim 48 \mathrm{~h}$ at $-70^{\circ} \mathrm{C}$ and 0.013 mbar with a Labconco freeze dryer system (Lyph Lock 6, Labconco, USA).

\section{Total phenolic content (TPC)}

The total phenolic content (TPC) in bean extracts was determined by a colorimetric method with Folin \& Ciocalteu's phenol (FCP) reagent [Amarowicz et al., 1996]. Briefly, solutions of extracts $(0.25 \mathrm{~mL})$ were mixed with $0.25 \mathrm{~mL}$ of the FCP reagent, $0.5 \mathrm{~mL}$ of a aqueous saturated solution of $\mathrm{Na}_{2} \mathrm{CO}_{3}$ and $4 \mathrm{~mL}$ of water. After 25 -min standing in dark, the samples were centrifuged (MPW-350R, MPW Med. Instruments, Poland) for $5 \mathrm{~min}$ at $5000 \times \mathrm{g}$. Absorbance of supernatants was recorded at $725 \mathrm{~nm}$ (DU-7500 spectrophotometer, Beckman Instruments, USA). Total phenolic content was expressed in two ways: as mg gallic acid equivalents (GAE) per $g$ of extract and as mg gallic acid equivalents per $\mathrm{g}$ of seeds.

\section{Trolox Equivalent Antioxidant Capacity (TEAC)}

The Trolox Equivalent Antioxidant Capacity (TEAC) was determined by using the method of Re et al. [1999]. For this assay, 2,2'-azino-bis(3-ethylbenzothiazoline-6-sulfonic acid) cation radical $\left(\mathrm{ABTS}^{\cdot+}\right)$ solution was prepared by dissolving $96 \mathrm{mg}$ of ABTS in $2.45 \mathrm{mmol} / \mathrm{L} \mathrm{Na}_{2} \mathrm{~S}_{2} \mathrm{O}_{8}$. This mixture was shaken for $16 \mathrm{~h}$ at room temperature in the dark until reaching a stable oxidative state. Before analysis, the ABTS ${ }^{\cdot+}$ stock solution was diluted with methanol to an absorbance of $0.70 \pm 0.02$ at $734 \mathrm{~nm}$. For the spectrophotometric assay, $2 \mathrm{~mL}$ of the $\mathrm{ABTS}^{\cdot+}$ solution and $20 \mu \mathrm{L}$ of white bean extracts were mixed and the absorbance was recorded at $734 \mathrm{~nm}$ (DU-7500 spectrophotometer) after samples incubation at $30^{\circ} \mathrm{C}$ for 6 min (TH-24 block heater, Meditherm, Poland). The calibration curve was plotted by using 6-hydroxy-2,5,7,8-tetramethylchromane-2-carboxylic acid (Trolox) as a standard. The results were expressed as $\mu \mathrm{mol}$ Trolox equivalents per $g$ of extract or per $g$ of seeds.

\section{The Ferric-Reducing Antioxidant Power (FRAP)}

The Ferric-Reducing Antioxidant Power (FRAP) assay was performed as previously described by Benzie \& Strain [1996]. The sample solution analysed was first properly diluted with deionised water to fit within the linearity range. The working FRAP reagent was prepared by mix-

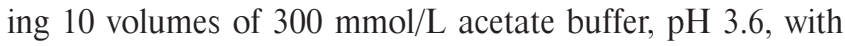
1 volume of $10 \mathrm{mmol} / \mathrm{L}$ 2,4,6-tris(2-pyridyl)-s-triazine (TPTZ) in $40 \mathrm{~mol} / \mathrm{L} \mathrm{HCl}$ and with 1 volume of $20 \mathrm{mmol} / \mathrm{L}$ $\mathrm{FeCl}_{3} \times 6 \mathrm{H}_{2} \mathrm{O}$. A volume of $2.25 \mathrm{~mL}$ of a working FRAP reagent was warmed to $37^{\circ} \mathrm{C}$. Then, $75 \mu \mathrm{L}$ of the sample and $225 \mu \mathrm{L}$ of deionised water were added to the FRAP reagent and the absorbance was taken at $593 \mathrm{~nm}$ against reagent blank after 30 min of incubation. FRAP value was calculated and expressed as $\mu \mathrm{mol} \mathrm{Fe}^{2+}$ equivalents per $\mathrm{g}$ of extract or per $\mathrm{g}$ of seeds (using the calibration curve prepared for $\mathrm{FeSO}_{4}$ ).

\section{Oxidation of $\boldsymbol{\beta}$-carotene-linoleic acid emulsion}

The antioxidant activity of white bean extracts in the $\beta$-carotene-linoleic acid model system was determined according to Miller [1971] assay with some modifications. $\beta$-Carotene ( $8 \mathrm{mg}$ ) was dissolved in $10 \mathrm{~mL}$ of chloroform. Portion of $2 \mathrm{~mL}$ of this solution was mixed with $400 \mathrm{mg}$ of Tween 40 and $40 \mu \mathrm{L}$ of linoleic acid. Then, chloroform was evaporated under nitrogen, residue was dissolved in $2 \mathrm{~mL}$ of methanol and $50 \mathrm{~mL}$ of deionised water were added with vigorous stirring. Oxidation of the emulsion was carried out on a 96-well plate and its bleaching was monitored using an Infinite M1000 microplate reader (Tecan, Switzerland) at $42^{\circ}$ C. Solutions of extracts or butylated hydroxyanisole (BHA) as a standard were dissolved in methanol $(2 \mathrm{mg} / \mathrm{mL})$ and pipetted on a plate $(10 \mu \mathrm{L})$. Afterwards, $250 \mu \mathrm{L}$ of the emulsion were added to each well. Absorbance readings at $470 \mathrm{~nm}$ were recorded at 15 min intervals during $180 \mathrm{~min}$. Results were expressed as percent of non-oxidised $\beta$-carotene.

\section{RP-HPLC analysis}

For the RP-HPLC fingerprint analysis of phenolic compounds present in the extracts a Shimadzu system (Shimadzu Co., Japan) consisting of two LC-10AD $\mathrm{vp}_{\mathrm{v}}$ pumps, SCL-10A system controller, SPD-M10A photo-diode array detector, and a pre-packed Luna C18 $(4 \times 250 \mathrm{~mm}$, particle size $5 \mu \mathrm{m}$, Phenomenex, USA) column was used. A flow rate of $1 \mathrm{~mL} / \mathrm{min}$ and gradient elution of solvent B (0-50 min) from 0 to $100 \%$ were applied, where solvent A was: acetonitrile-water-acetic acid (5:93:2, v/v/v) and solvent B was: acetonitrile-water-acetic acid (40:58:2, v/v/v). The concentration of sample dis- 
solved in methanol was $10 \mathrm{mg} / \mathrm{mL}$ and injection volume was $20 \mu \mathrm{L}$. The diode array detection was performed by scanning over a wavelength range from 200 to $400 \mathrm{~nm}$.

\section{Statistical analysis}

Three independent extractions were carried out for each white bean variety. Antioxidant activity assays and HPLC separations were conducted at least in three replications. Results were reported as mean and standard deviation values. Analyses of variance (one-way ANOVA) and the least significant difference (LSD) test were performed at a level of $\mathrm{P}<0.05$ to evaluate the significance of differences among mean values. The correlation between total phenolic content, content of individual compounds in extracts and antioxidant activities was analysed by the Pearson's test. Statistical package of MSTAT-C software was used.

\section{RESULTS AND DISCUSSION}

The total phenolic contents of ten varieties of white bean extracts and seeds are shown in Table 1. TPC ranged between $2.79 \mathrm{mg} \mathrm{GAE} / \mathrm{g}$ for the extract of Zülbiye var. and $5.34 \mathrm{mg}$ GAE/g for the extract of Göksun var. The highest TPC expressed per $\mathrm{g}$ of seed was found for two varieties named Göynük and Göksun, i.e. 0.63 and $0.61 \mathrm{mg}$ GAE/g, respectively. The difference between these results was statistically insignificant $(\mathrm{P}>0.05)$. Our results regarding the extracts were comparable to TEC values demonstrated by Karamać et al. [2004] for fractions obtained from the acetone extract of white bean. The total phenolic content of extracts of Göynük, Güngör and Göksun varieties was similar to the data achieved by Madhujith et al. [2004] for the extract of whole white bean (4.9 mg catechin equivalents/g). In turn, Agostini-Costa et al. [2015] reported the phenolic content of white lima beans conserved in a Brazilian Genebank between 0.1 and $2.1 \mathrm{mg}$ GAE/g dry bean. But generally, some earlier comparative studies conducted for different legumes and different bean varieties demonstrated that the TPC of white beans was lower than of some other legume seeds and coloured bean [Xu et al., 2007; Djordjevic et al., 2011]. Akond et al. [2011] observed differences in TPC of white, red and black common beans in the range of $5.87-14.14 \mathrm{mg} / \mathrm{g}$. According to Madhujith \& Shahidi [2005] and Oomah et al. [2005], white bean had the least amount of phenolics as compared to other colourful bean. The total phenolic content of white beans determined in our study was lower than results achieved for red bean, black bean, red lentil, green lentil, however comparable to values obtained for green pea, yellow pea and chickpea [Amarowicz \& Pegg, 2008]. Marathe et al. [2011] categorised the legumes depending on their phenolic content into three groups, as low ( $<1.0 \mathrm{mg} \mathrm{GAE} / \mathrm{g})$, moderate (1.0-2.0 mg GAE/g) and high (>2.0 mg GAE/g). White beans were classified as low content phenolic legumes together with chick pea (cream, green), pea (white, green) and lentil.

The antioxidant activity of white bean extracts was evaluated in two polar systems, as the ability to scavenge radicals and the ability to reduce $\mathrm{Fe}^{3+}$ using ABTS and FRAP assays, respectively, and in one lipid system, as the ability to inhibit oxidation of $\beta$-carotene-linoleic acid emulsion. Re-
TABLE 1. Extraction yield and total phenolic content of white bean varieties in extracts and seeds.

\begin{tabular}{|c|c|c|c|}
\hline \multirow{2}{*}{ Variety } & \multirow{2}{*}{$\begin{array}{c}\text { Extract yield } \\
\text { (g /100 g seeds) }\end{array}$} & \multicolumn{2}{|c|}{ Total phenolic content* } \\
\hline & & $\begin{array}{c}\text { mg GAE/g } \\
\text { extract }\end{array}$ & $\begin{array}{c}\mathrm{mg} \mathrm{GAE} / \mathrm{g} \\
\text { seed }\end{array}$ \\
\hline Göynük & 12.92 & $4.91 \pm 0.38^{a}$ & $0.63 \pm 0.04^{\mathrm{a}}$ \\
\hline Güngör & 12.14 & $4.05 \pm 0.27^{\mathrm{b}}$ & $0.49 \pm 0.03^{b}$ \\
\hline Noyanbey & 12.98 & $3.47 \pm 0.05^{\mathrm{c}}$ & $0.45 \pm 0.01^{\mathrm{c}}$ \\
\hline Şehirali & 11.24 & $3.84 \pm 0.14^{\mathrm{bc}}$ & $0.43 \pm 0.02^{c}$ \\
\hline Yunus 90 & 10.77 & $3.46 \pm 0.09^{\mathrm{c}}$ & $0.37 \pm 0.05^{\mathrm{d}}$ \\
\hline İspir & 12.47 & $3.41 \pm 0.11^{\mathrm{c}}$ & $0.43 \pm 0.03^{c}$ \\
\hline Göksun & 11.48 & $5.34 \pm 0.11^{\mathrm{a}}$ & $0.61 \pm 0.05^{\mathrm{a}}$ \\
\hline Akman & 10.92 & $3.14 \pm 0.32^{\mathrm{d}}$ & $0.34 \pm 0.06^{\mathrm{e}}$ \\
\hline Zülbiye & 11.75 & $2.79 \pm 0.14^{\mathrm{e}}$ & $0.33 \pm 0.02^{\mathrm{e}}$ \\
\hline Karacaşehir & 10.56 & $3.53 \pm 0.15^{\mathrm{c}}$ & $0.37 \pm 0.05^{\mathrm{d}}$ \\
\hline
\end{tabular}

*Data are expressed as the mean \pm standard deviation $(n=3)$. Values in the same column having different letters differ significantly $(\mathrm{P}<0.05)$.

sults of TEAC determined by the ABTS assay were given in Figure 1. This assay is based on the scavenging ability of antioxidants to the relatively stable blue/green $\mathrm{ABTS}^{\cdot+}$. The degree of cation radicals decolourisation is correlated with the sample's antioxidant capacity [Prior et al., 2005]. The range of TEAC of white bean extracts was from $27 \mu \mathrm{mol}$ Trolox/g (Noyanbey) to $43 \mu \mathrm{mol}$ Trolox/g (Göksun) (Figure 1A). The antioxidant potential of seeds showed that Göynük, Göksun, Akman and İspir varieties were characterised by the highest TEAC (Figure 1B). Statistical evaluations indicated that differences in the antiradical activity against $\mathrm{ABTS}^{\cdot+}$ between these varieties were insignificant $(\mathrm{P}>0.05)$. The extracts of white beans exhibited a lower antioxidant activity than those of broad bean $(0.58 \mu \mathrm{mol}$ Trolox $/ \mathrm{mg}$ extract), red lentil $(0.68 \mu \mathrm{mol}$ Trolox/mg extract), adzuki bean (1.76 $\mu \mathrm{mol}$ Trolox/mg extract) and red bean (0.19-0.49 mmol Trolox/g extract) as previously reported by Amarowicz et al. [2004; 2008] and Orak et al. [2015]. On the other hand, our results were comparable to TEAC of flours of black and brown seeds of Phaseolus vulgaris L. cultivated in three years (2.77-5.23 and 2.28-5.19 $\mu \mathrm{mol}$ Trolox/g, respectively) [Ramirez-Jiménez et al., 2014]. Marathe et al. [2011] found TEAC on a similar level for pea, chickpea and lablab bean. The same authors determined the antiradical activity against $\mathrm{ABTS}^{\cdot+}$ of white common bean $(6.04 \mu \mathrm{mol}$ Trolox/g), which was lower than the values obtained for common beans with colourful coats (10.1-23.8 $\mu \mathrm{mol}$ Trolox/g).

One of the mode of action of antioxidants is their ability to participate in redox reactions and reduction of oxidants. The FRAP assay measures the antioxidant effects of any substance in the reaction medium as reducing power. Regarding this method, the results for extracts and seeds of white bean varieties were shown in Figure $2 \mathrm{~A}$ and $2 \mathrm{~B}$, respectively. The highest reducing power was obtained for extracts of Göksun, Göynük, Güngör and Şehirali and the lowest one for 
(A)

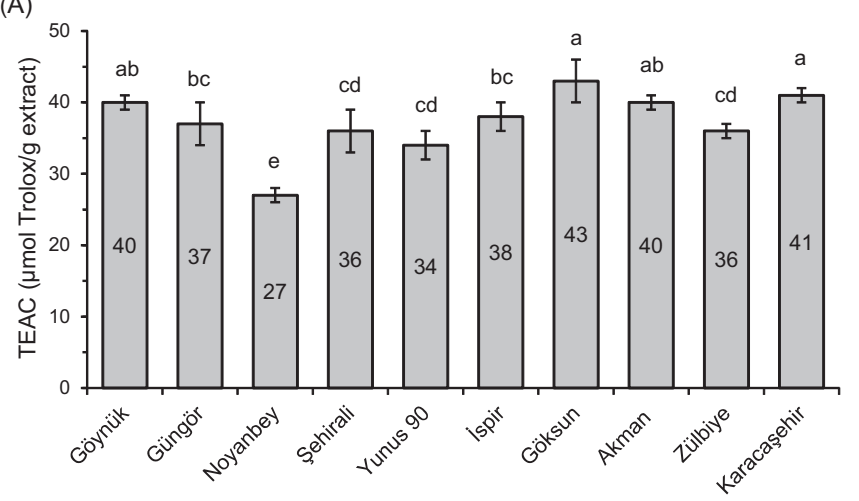

(B)

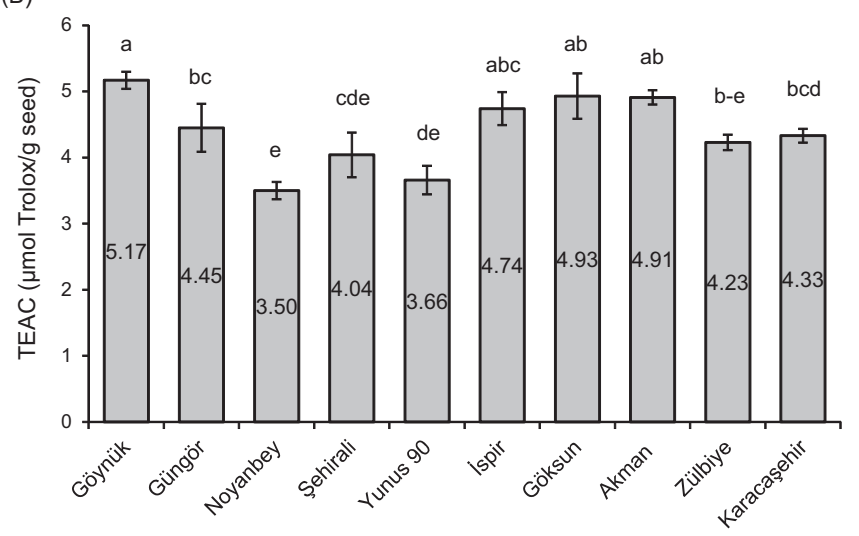

FIGURE 1. Trolox Equivalent Antioxidant Capacity (TEAC) of white bean extracts (A) and seeds (B). Data are expressed as the mean \pm standard deviation $(n=3)$. On particular subgraphs values having different letters differ significantly $(\mathrm{P}<0.05)$.

extracts of Noyanbey and Zülbiye varieties (Figure 2A). But it should be noted that the range of $\mathrm{Fe}^{3+}$ reducing capability of the examined extracts was narrow, from $66 \mu \mathrm{mol} \mathrm{Fe}{ }^{2+} / \mathrm{g}$ to $89 \mu \mathrm{mol} \mathrm{Fe}{ }^{2+} / \mathrm{g}$. Greater differences were observed between bean varieties when FRAP results were expressed in $\mathrm{g}$ of seeds (Figure 2B). The strongest reducing power was found for Göynük seeds $\left(11.2 \mu \mathrm{mol} \mathrm{Fe}{ }^{2+} / \mathrm{g}\right)$. The demonstrated ability of white bean to reduce $\mathrm{Fe}^{3+}$ was lower than the results obtained by Djordjevic et al. [2011] and Orak et al. [2015] for extract of mung bean, red kidney bean and red common bean, and comparable to the results reported by $\mathrm{Xu}$ et al. [2007] and Marathe et al. [2011], who found the FRAP of navy beans and white common beans at $1.27 \mathrm{mmol} \mathrm{Fe}{ }^{2+} / 100 \mathrm{~g}$ and $10.2 \mu \mathrm{mol} \mathrm{Fe} \mathrm{F}^{2+} / \mathrm{g}$, respectively. On the other hand, Chen et al. [2015] reported that no reducing power was apparent for non-darkening cranberry beans.

Figure 3 presents the antioxidant activity of extracts of white beans in the $\beta$-carotene-linoleic acid model system. In this assay, decolourisation of $\beta$-carotene is due to its oxidation induced by peroxy radicals generated from linoleic acid autoxidation. Antioxidants added to the emulsion quench radicals and inhibit this process [Prior et al., 2005]. Kinetics of oxidation in the model system was similar for all tested white bean extracts (Figure 3A). The determined oxidation curves had a typical shape and were comparable to these plotted in previous investigations for legume seed extracts [Amarowicz et al., 1996; 2008; Karamać et al., 2004]. In our study, after $180 \mathrm{~min}$ of the process, the highest percentage of non-
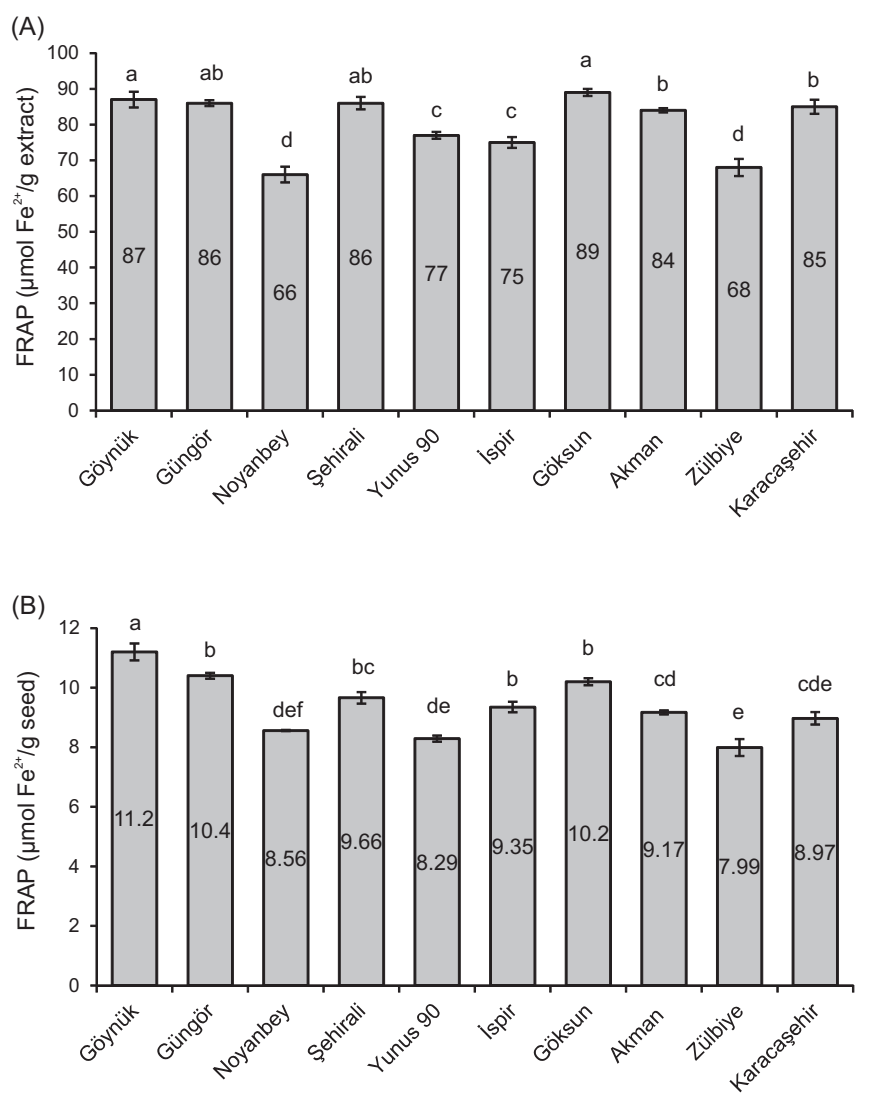

FIGURE 2. Ferric-Reducing Antioxidant Power (FRAP) of white bean extracts (A) and seeds (B). Data are expressed as the mean \pm standard deviation $(n=3)$. On particular subgraphs values having different letters differ significantly $(\mathrm{P}<0.05)$.

-oxidised $\beta$-carotene $(37.8 \%)$ remained in the emulsion with the addition of an extract from Yunus 90 (Figure 3B). A lower antioxidant activity in the $\beta$-carotene-linoleic acid system was assayed only for extracts from Göynük and Akman varieties. Differences between the remaining results were statistically insignificant $(\mathrm{P}>0.05)$. Karamać et al. [2004] observed similar inhibition of the oxidation of a model emulsion by fractions with phenolic compounds contents at 5.6-6.7 mg/g obtained from white bean extract. Other authors report that, likewise in the polar systems, also during oxidation in the $\beta$-carotene-linolenic acid system the antioxidant activity of white bean extracts was lower compared to the extracts from Phaseolus vulgaris L. seeds with colourful coat [Madhujith et al., 2004; Oomah et al., 2005].

Substantially greater differences in the antioxidative activity determined between white bean varieties in FRAP and ABTS assays (Figures 1 and 2), compared to practically no differences between the varieties in the $\beta$-carotene-linoleic acid model system (Figure 3), may be explained by various mechanisms of action of the antioxidants in the applied tests. Antioxidants in FRAP and ABTS assays react by hydrogen atom transfer and the mode of action of antioxidants during emulsion oxidation involves radicals quenching by single electron transfer [Prior et al., 2005]. This phenomena suggested that the white bean extracts contained some phenolic compounds which were more active in the FRAP and ABTS assays (polar systems) and some other - in the lipid system with $\beta$-carotene and linoleic acid. 

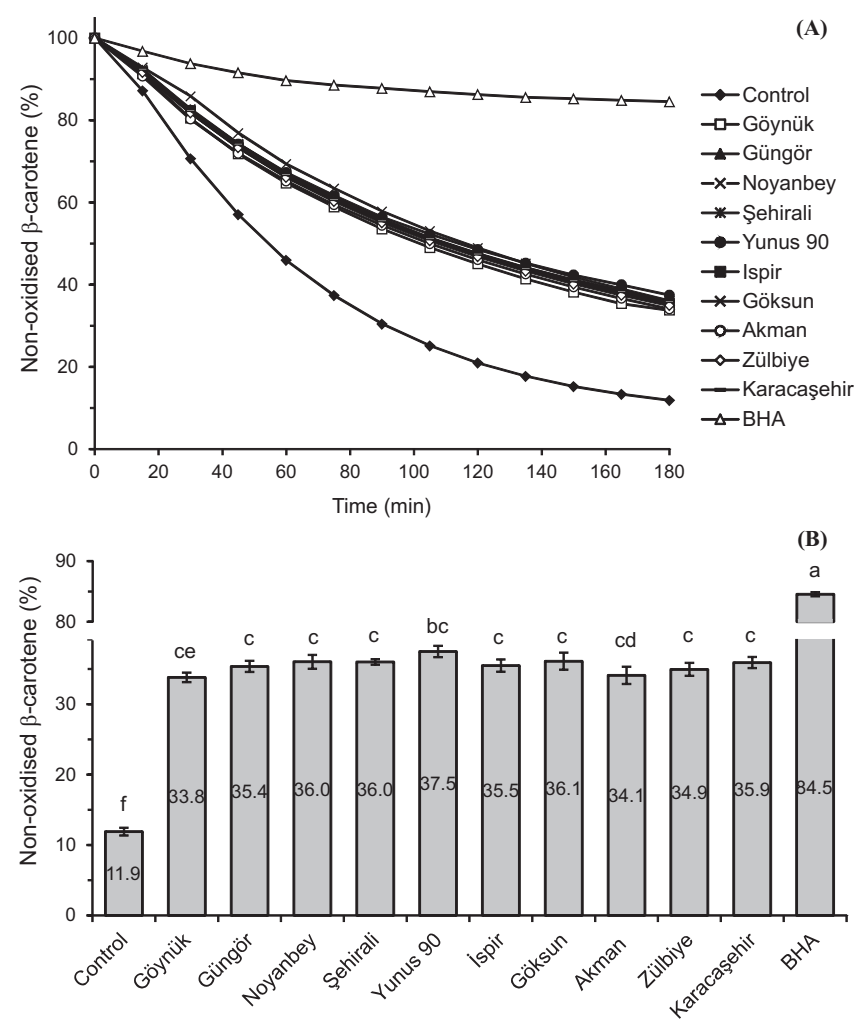

FIGURE 3. Antioxidant activity of white bean extracts in $\beta$-carotenelinoleic acid model system. (A) - kinetic of emulsion oxidation; (B) non-oxidised $\beta$-carotene after 180 min of oxidation of model emulsion. Data are expressed as the mean \pm standard deviation $(n=4)$. On subgraph $\mathrm{B}$ values having different letters differ significantly $(\mathrm{P}<0.05)$.

A representative chromatogram of the RP-HPLC fingerprint analysis of white bean extracts was shown in Figure 4. Five peaks with retention times at 23.5, 27.5, 29.8, 32.2, and 33.1 min dominated on chromatograms from the separation of extracts of all varieties. The UV-DAD spectra corresponding to the above peaks (compounds 1-5), with the maximum absorption at 324-328 $\mathrm{nm}$ and shoulders at short wavelength, were presented in Figure 5. Spectra of caffeic, ferulic or chlorogenic acids were characterised by similar shapes,

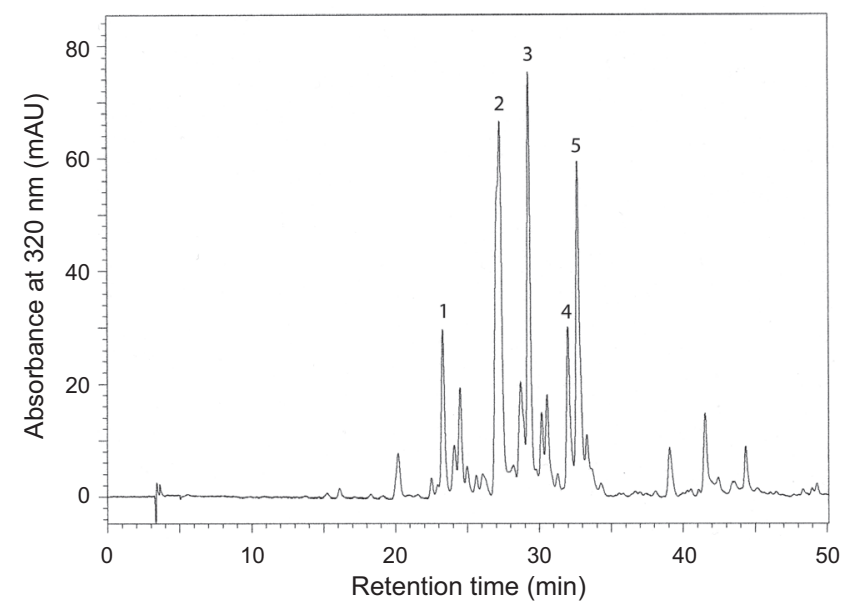

FIGURE 4. HPLC chromatogram of phenolic compounds of white bean methanolic extract recorded at $320 \mathrm{~nm}$. but the retention times of these standards did not correspond to any of the compounds 1-5 (data not shown). Based on UV-DAD spectra, it could be assumed that compounds 1-5 were ferulic or caffeic acid derivatives. Table 2 summarises contents of phenolic compounds $1-5$ in the white bean extracts and seeds expressed as caffeic acid equivalents. The highest content of compound 1 was determined in seeds of Göynük var. $(0.028 \mathrm{mg} / \mathrm{g})$. Compound 2 was found in the highest amount in seeds of Göksun and İspir var. In turn compound 3 was predominating in seeds of Akman var. $(0.069 \mathrm{mg} / \mathrm{g}$ ) and the highest content of compound 4 was noted in Göksun and Göynük var. Noyanbey was the variety with the highest content of compound $5(0.053 \mathrm{mg} / \mathrm{g})$. As mentioned above, free caffeic, ferulic, chlorogenic and neochlorogenic acids were not identified in the extracts of white beans. None of the spectra corresponding to the peaks on the chromatograms and retention times of peaks confirmed the presence of free gallic, $p$-coumaric, sinapic acids and rutin, quercetin and kaempferol in extracts, too. The lack of the above-listed free phenolic acids in white bean was in accordance with the study of Ross et al. [2009], who did not find these phenolic acids in the free form in pinto bean, black bean and dark red kidney bean, although these acids were determined after alkaline hydrolysis. Similarly, Luthria \& Pastor-Corrales [2006] showed that insignificant amounts of free phenolic acids were extracted from beans of fifteen varieties of $P$. vulgaris and that after hydrolysis ferulic, $p$-coumaric and sinapic acids were released. Ferulic acid was the most abundant. Liberated
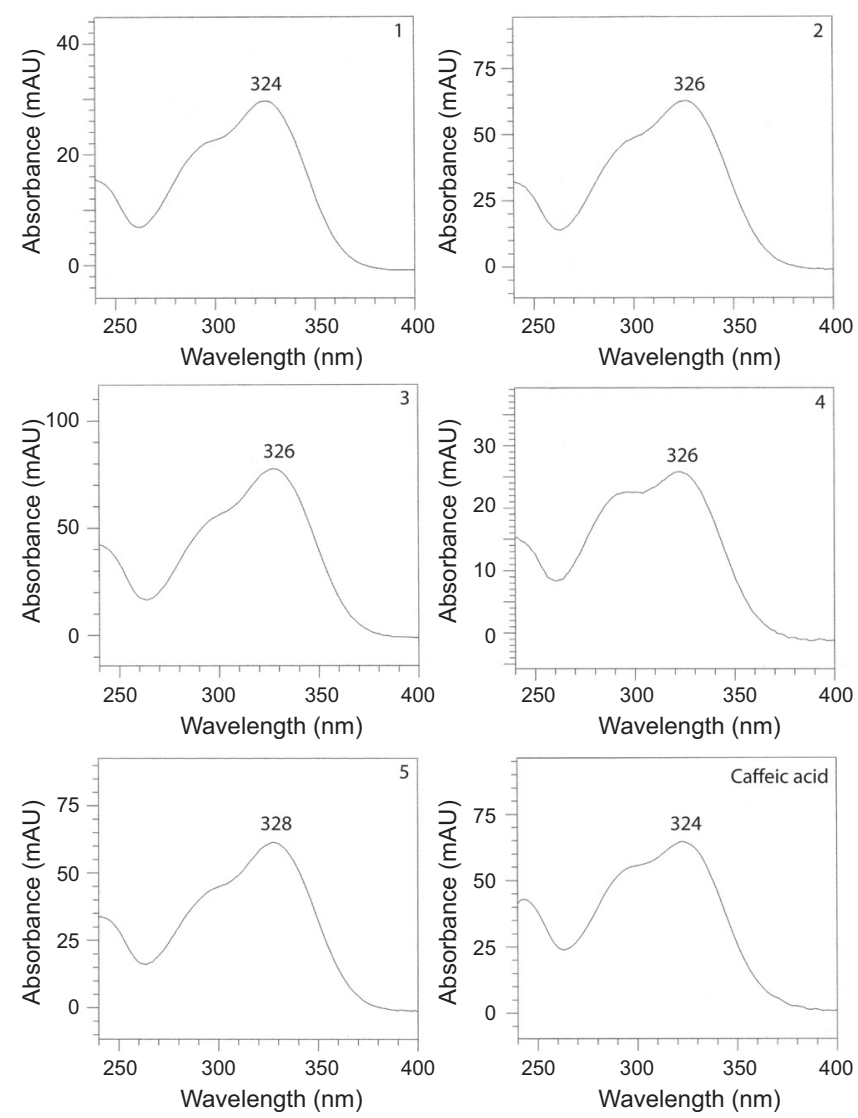

FIGURE 5. UV-DAD spectra of compounds 1-5 shown in Figure 4 and standard of caffeic acid. 
TABLE 2. Content of individual phenolic compounds in white bean extracts and seeds.

\begin{tabular}{|c|c|c|c|c|c|c|c|c|c|c|}
\hline \multirow{2}{*}{ Variety } & \multicolumn{2}{|c|}{ Compound $1 *$} & \multicolumn{2}{|c|}{ Compound $2^{*}$} & \multicolumn{2}{|c|}{ Compound $3^{*}$} & \multicolumn{2}{|c|}{ Compound $4^{*}$} & \multicolumn{2}{|c|}{ Compound $5^{*}$} \\
\hline & $\begin{array}{c}\mathrm{mg} / \mathrm{g} \\
\text { extract }\end{array}$ & $\mu \mathrm{g} / \mathrm{g}$ seed & $\begin{array}{c}\mathrm{mg} / \mathrm{g} \\
\text { extract }\end{array}$ & $\mu \mathrm{g} / \mathrm{g}$ seed & $\begin{array}{c}\mathrm{mg} / \mathrm{g} \\
\text { extract }\end{array}$ & $\mu \mathrm{g} / \mathrm{g}$ seed & $\mathrm{mg} / \mathrm{g}$ extract & $\mu \mathrm{g} / \mathrm{g}$ seed & $\begin{array}{c}\mathrm{mg} / \mathrm{g} \\
\text { extract }\end{array}$ & $\mu \mathrm{g} / \mathrm{g}$ seed \\
\hline Göynük & $0.22 \pm 0.01^{\mathrm{a}}$ & $28 \pm 0.8^{\mathrm{a}}$ & $0.15 \pm 0.01^{\mathrm{f}}$ & $19 \pm 0.7^{\mathrm{h}}$ & $0.49 \pm 0.03^{\mathrm{cd}}$ & $63 \pm 2.7^{b}$ & $0.20 \pm 0.01^{\mathrm{abc}}$ & $26 \pm 1.3^{\mathrm{ab}}$ & $0.27 \pm 0.02^{\mathrm{d}}$ & $35 \pm 1.6^{\mathrm{d}}$ \\
\hline Güngör & $0.11 \pm 0.01^{\mathrm{e}}$ & $13 \pm 0.6^{\mathrm{e}}$ & $0.22 \pm 0.01^{\mathrm{e}}$ & $27 \pm 1.3^{\mathrm{g}}$ & $0.28 \pm 0.01^{\mathrm{h}}$ & $34 \pm 1.0^{\mathrm{g}}$ & $0.17 \pm 0.01^{\text {cde }}$ & $21 \pm 0.8^{c}$ & $0.19 \pm 0.01^{\mathrm{f}}$ & $23 \pm 0.8^{g}$ \\
\hline Noyanbey & $0.11 \pm 0.01^{\mathrm{e}}$ & $14 \pm 0.8^{\mathrm{e}}$ & $0.21 \pm 0.01^{\mathrm{e}}$ & $27 \pm 0.8^{g}$ & $0.41 \pm 0.02^{\mathrm{g}}$ & $53 \pm 1.8^{d}$ & $0.15 \pm 0.01^{\mathrm{e}}$ & $19 \pm 0.6^{c}$ & $0.41 \pm 0.02^{\mathrm{a}}$ & $53 \pm 1.9^{\mathrm{a}}$ \\
\hline Şehirali & $0.22 \pm 0.01^{\mathrm{a}}$ & $25 \pm 0.9^{b}$ & $0.43 \pm 0.02^{\mathrm{a}}$ & $48 \pm 1.7^{c}$ & $0.56 \pm 0.03^{\mathrm{b}}$ & $63 \pm 2.6^{\mathrm{bc}}$ & $0.16 \pm 0.01^{\mathrm{de}}$ & $18 \pm 0.7^{\mathrm{cd}}$ & $0.23 \pm 0.01^{\mathrm{e}}$ & $26 \pm 1.0$ \\
\hline Yunus90 & $0.17 \pm 0.01^{\mathrm{cd}}$ & $18 \pm 0.6^{\mathrm{d}}$ & $0.29 \pm 0.02^{\mathrm{d}}$ & $31 \pm 1.6^{\mathrm{f}}$ & $0.38 \pm 0.02^{\mathrm{g}}$ & $41 \pm 1.5^{\mathrm{f}}$ & $0.19 \pm 0.01^{\mathrm{bc}}$ & $20 \pm 0.8^{\mathrm{d}}$ & $0.29 \pm 0.02^{\mathrm{d}}$ & $31 \pm 1.6^{\mathrm{e}}$ \\
\hline İspir & $0.16 \pm 0.01^{\mathrm{d}}$ & $19 \pm 0.7^{\mathrm{d}}$ & $0.45 \pm 0.02^{\mathrm{a}}$ & $56 \pm 1.7^{\mathrm{a}}$ & $0.48 \pm 0.03^{\mathrm{de}}$ & $59 \pm 2.6^{\mathrm{cd}}$ & $0.17 \pm 0.01^{\text {cde }}$ & $21 \pm 0.8^{c}$ & $0.27 \pm 0.02^{\mathrm{d}}$ & $34 \pm 1.7^{\mathrm{d}}$ \\
\hline Göksun & $0.19 \pm 0.01^{\mathrm{b}}$ & $22 \pm 1.2^{\mathrm{c}}$ & $0.46 \pm 0.02^{\mathrm{a}}$ & $53 \pm 1.8^{\mathrm{a}}$ & $0.49 \pm 0.02^{\mathrm{cd}}$ & $56 \pm 2.2^{\mathrm{de}}$ & $0.25 \pm 0.01^{\mathrm{a}}$ & $29 \pm 1.2^{\mathrm{a}}$ & $0.37 \pm 0.02^{\mathrm{b}}$ & $42 \pm 2$ \\
\hline Akman & $0.18 \pm 0.01^{b c}$ & $19 \pm 0.9^{d}$ & $0.46 \pm 0.03^{\mathrm{a}}$ & $50 \pm 2.6^{\mathrm{bc}}$ & $0.64 \pm 0.04^{\mathrm{a}}$ & $69 \pm 3.6^{\mathrm{a}}$ & $0.23 \pm 0.01^{\mathrm{ab}}$ & $25 \pm 0.9^{b}$ & $0.36 \pm 0.02^{\mathrm{bc}}$ & $39 \pm 1.8^{\mathrm{bc}}$ \\
\hline Zülbiye & $0.17 \pm 0.01^{\mathrm{cd}}$ & $19 \pm 0.8^{\mathrm{d}}$ & $0.39 \pm 0.02^{\mathrm{b}}$ & $46 \pm 1.1^{\mathrm{d}}$ & $0.44 \pm 0.02^{\mathrm{ef}}$ & $52 \pm 2.4^{e}$ & $0.21 \pm 0.01^{\mathrm{ab}}$ & $25 \pm 0.7^{b}$ & $0.33 \pm 0.02^{\mathrm{c}}$ & $39 \pm 2.2^{\mathrm{c}}$ \\
\hline Karacaşehir & $0.17 \pm 0.01^{\mathrm{cd}}$ & $18 \pm 0.7^{\mathrm{d}}$ & $0.34 \pm 0.02^{\mathrm{b}}$ & $36 \pm 1.6^{\mathrm{e}}$ & $0.53 \pm 0.03^{\mathrm{bc}}$ & $56 \pm 2.7^{\mathrm{de}}$ & $0.20 \pm 0.01^{\mathrm{abc}}$ & $21 \pm 1.0^{\mathrm{c}}$ & $0.27 \pm 0.02^{\mathrm{d}}$ & $28 \pm 1.5^{\mathrm{f}}$ \\
\hline
\end{tabular}

*Contents of compounds 1-5 are expressed as caffeic acid equivalents. Data are reported as the mean \pm standard deviation $(\mathrm{n}=3)$. In the same column values having different letters differ significantly $(\mathrm{P}<0.05)$.

TABLE 3. Correlation coefficients (r) between the content of total phenolic compounds, content of individual phenolics and results of antioxidant activities of white bean extracts.

\begin{tabular}{|c|c|c|c|c|c|c|c|c|c|}
\hline & $\begin{array}{c}\text { Compound } \\
1 \\
\end{array}$ & $\begin{array}{c}\text { Compound } \\
2 \\
\end{array}$ & $\begin{array}{c}\text { Compound } \\
3 \\
\end{array}$ & $\begin{array}{c}\text { Compound } \\
4 \\
\end{array}$ & $\begin{array}{c}\text { Compound } \\
5 \\
\end{array}$ & ТPC & FRAP & TEAC & $\begin{array}{c}\text { Non-oxidised } \\
\beta \text {-carotene }\end{array}$ \\
\hline Compound 1 & 1 & $0.292^{\mathrm{ns}}$ & $0.624^{* *}$ & $0.245^{\mathrm{ns}}$ & $-0.142^{\mathrm{ns}}$ & $0.336^{\text {ns }}$ & $0.455^{*}$ & $0.459^{*}$ & $-0.283^{\text {ns }}$ \\
\hline Compound 2 & & 1 & $0.593^{\text {** }}$ & $0.401^{*}$ & $0.185^{\text {ns }}$ & $-0.202^{\mathrm{ns}}$ & $0.109^{\text {ns }}$ & $0.481^{\text {** }}$ & $0.089^{\mathrm{ns}}$ \\
\hline Compound 3 & & & 1 & $0.394^{*}$ & $0.285^{\mathrm{ns}}$ & $0.055^{\mathrm{ns}}$ & $0.296^{\mathrm{ns}}$ & $0.573^{* *}$ & $-0.326^{\mathrm{ns}}$ \\
\hline Compound 4 & & & & 1 & $0.382^{*}$ & $0.258^{\mathrm{ns}}$ & $0.399^{*}$ & $0.750^{* *}$ & $-0.026^{\mathrm{ns}}$ \\
\hline Compound 5 & & & & & 1 & $0.164^{\mathrm{ns}}$ & $-0.230^{\mathrm{ns}}$ & $0.093^{\mathrm{ns}}$ & $0.086^{\mathrm{ns}}$ \\
\hline ТPC & & & & & & 1 & $0.850^{* *}$ & $0.480^{\text {** }}$ & $-0.064^{\mathrm{ns}}$ \\
\hline FRAP & & & & & & & 1 & $0.734^{* *}$ & $-0.165^{\text {ns }}$ \\
\hline TEAC & & & & & & & & 1 & $-0.370^{*}$ \\
\hline $\begin{array}{l}\text { Non-oxidised } \\
\beta \text {-carotene }\end{array}$ & & & & & & & & & 1 \\
\hline
\end{tabular}

${ }^{*}$ Correlation is significant at $\mathrm{P}<0.05 .{ }^{* *}$ Correlation is significant at $\mathrm{P}<0.01$. ${ }^{\text {ns }}$ Correlation is not significant.

caffeic acid was determined only in two varieties. The same four phenolic acids were identified in white bean [Karamać et al., 2004]. Most of them were present in the esterified form. The HPLC-MS analysis of crude extract of adzuki bean allowed indicating to presence of 29 phenolic compounds belonging mainly to the class of flavonoids [Amarowicz et al., 2008]. Flavan-3-ol glycosides and oligomers and quercetin glycosides were predominating. Among phenolic acids only protocatechuic and $p$-coumaric acids and their two derivatives (protocatechuic aldehyde and $p$-coumaroyl malic acid) were determined. Derivatives of caffeic and ferulic acids were not found. Among phenolic acid derivatives, Moreno-Jiménez et al. [2015] identified $p$-coumaricaldaric acid isomers and sinapylaldaric in four dry bean cultivars. In turn Chen et al. [2015] did not identify any derivatives of phenolic acids by carrying out fingerprint HPLC-MS/MS analysis of regu- lar-darkening and non-darkening cranberry beans, although free ferulic, $p$-coumaric and sinapic acids were determined after alkaline hydrolysis of the extracts. The authors explained this phenomenon with the limitation of RP-HPLC separation procedure of conjugated phenolics in crude extracts. The quantitative analysis of phenolic compounds showed that regular-darkening beans contained mainly flavonoids (especially flavan-3-ols), while phenolic acids were predominating in non-darkening varieties.

The results of correlation analyses made for the content of total phenolic compounds, content of individual phenolics and antioxidant activities between white bean extracts were presented in Table 3. Significant $(\mathrm{P}<0.01)$, strong correlations were found between TPC and FRAP $(r=0.850)$ and between TEAC and FRAP $(r=0.734)$. Similar strong correlations between reducing power and total phenolic 
content of legume seeds were reported by Xu et al. [2007], Marathe et al. [2011] and Chen et al. [2015]. A high correlation coefficient determined for TEAC and FRAP values was not surprising considering the fact that similar compounds react in both the TEAC and FRAP assays due to a comparable redox potential of $\mathrm{Fe}^{3+}-\mathrm{TPTZ}$ and $\mathrm{ABTS}{ }^{\cdot+}$ [Prior et al., 2005]. In our study, a significant $(\mathrm{P}<0.01)$ correlation was determined between TPC and TEAC. But it was weaker $(\mathrm{r}=0.480)$ than that showed previously by Amarowicz et al. [2004] for extracts of legume seeds. The obtained results revealed that there was an insignificant correlation between TPC and antioxidant activity in the $\beta$-carotene-linoleic acid model system (Table 3). According to Oomah et al. [2005], means of expressing the values of $\beta$-carotene bleaching assay affect coefficients of correlation between antioxidant activity and TPC.

Significant $(\mathrm{P}<0.01)$ correlations were found between the content of individual phenolic compounds and TEAC (Table 3 ). The results obtained suggest that compound 4 contributed the most to the TEAC in white bean $(r=0.750)$. The coefficients of correlation between the content of other phenolic compounds and TEAC were in the following order: compound $3>$ compound $2>$ compound 1 . There was also a significant correlation between FRAP values and contents of compound $1(\mathrm{r}=0.455)$ and $4(\mathrm{r}=0.399)$, while insignificant correlations existed between the content of other individual phenolics and FRAP. Chen et al. [2015] also found insignificant contributions of hydroxycinnamic acids such as $p$-coumaric, ferulic, and sinapic acid to FRAP in the bound phenolic fraction of regular-darkening and non-darkening cranberry beans varieties. Correlations between the content of individual phenolic compounds in extracts and their antioxidant activity in the $\beta$-carotene-linoleic acid system were not confirmed (Table 3).

\section{CONCLUSIONS}

In the presented study we compared the antioxidant potential and content of phenolics of ten common bean varieties with white coats, widely produced and consumed in Turkey. Beans differed in total phenolic compounds content. Varieties Göynük and Göksun contained almost two times more phenolics than Zülbiye. The variety with high TPC was characterised by high antioxidant potential in the polar system FRAP and ABTS assays. A significant $(\mathrm{P}<0.01)$ correlation was found between TPC, FRAP and TEAC. A lower antiradical activity against $\mathrm{ABTS}^{\bullet+}$ and reducing power were noted for Zülbiye, Noyanbey and Yunus 90 varieties. In contrast, in $\beta$-carotene-linoleic acid emulsion, the antioxidant activity was comparable for all extracts.

The five main phenolic compounds in each of extracts were caffeic or ferulic acid derivatives. The presence of flavonoids or free phenolic acids in extracts was not indicated. Unfortunately, we did not have the possibility to fully describe the structures of the determined compounds. But on the basis of correlation analysis, it could be concluded that four of the identified caffeic or ferulic acids derivatives contributed to TEAC (compounds 1-4) and FRAP (compounds 1 and 4) of white bean. In turn, the significance of these compounds as antioxidants was not so obvious in the $\beta$-carotene-linoleic acid emulsion.

\section{ACKNOWLEDGEMENTS}

This work was performed at the Department of Chemical and Physical Properties of Food of the Institute of Animal Reproduction and Food Research Polish Academy of Sciences in Olsztyn, Poland.

\section{REFERENCES}

1. Agostini-Costa T.S., Teodoro A.F.P., Alves R.B.N., Braga L.R., Ribeiro I.F., Silva J.P., Quintana L.G., Burle M.L., Total phenolics, flavonoids, tannins and antioxidant activity of Lima Beans conserved in a Brazilian Genebank. Cienc. Rural., 2015, 45, 335-341.

2. Akond A.S.M.G.M., Khandaker L., Berthold J., Gates L., Peters K., Delong H., Hossain K., Anthocyanin, total polyphenols and antioxidant activity of common bean. Am. J. Food Technol., 2011, 6, 385-394.

3. Amarowicz R., Karamać M., Kmita-Głażewska H., Troszyńska A., Kozłowska H., Antioxidant activity of phenolic fractions of everlasting pea, faba bean and broad bean. J. Food Lipids, 1996, 3, 199-211.

4. Amarowicz R., Troszyńska A., Baryłko-Pikielna N., Shahidi F., Polyphenolics extracts from legume seeds: Correlations between total antioxidant activity, total phenolics content, tannins content and astringency. J. Food Lipids, 2004, 11, 278-286.

5. Amarowicz R., Pegg R.B., Legumes as a source of natural antioxidants. Eur. J. Lipid Sci. Technol., 2008, 110, 865-878.

6. Amarowicz R., Estrella I., Hernández T., Troszyńka A., Antioxidant activity of extract of adzuki bean and its fractions. J. Food Lipids, 2008, 15, 119-136.

7. Anton A.A., Gary Fulcher R.G., Arntfield S.D., Physical and nutritional impact of fortification of corn starch-based extruded snacks with common bean (Phaseolus vulgaris L.) flour: Effects of bean addition and extrusion cooking. Food Chem., 2009, 113, 989-996.

8. Benzie I.F.F., Strain J.J., The Ferric Reducing Ability of Plasma (FRAP) as a measure of "antioxidant power": the FRAP assay. Anal Biochem., 1996, 239, 70-76.

9. Boye J., Zare F., Pletch A., Pulse proteins: Processing, characterization, functional properties and applications in food and feed. Food Res. Int., 2010, 43, 414-431.

10. Câmara C.R.S., Urrea C.A., Schlegel V., Pinto beans (Phaseolus vulgaris L.) as a functional food: Implications on human health. Agriculture, 2013, 3, 90-111.

11. Chen P.X., Tang Y., Marcone M.F., Pauls P.K., Zhang B., Liu R., Tsao R., Characterization of free, conjugated and bound phenolics and lipophilic antioxidants in regular and non-darkening cranberry beans (Phaseolus vulgaris L.). Food Chem., 2015, 185, 298-308.

12. Curran J., The nutritional value and health benefits of pulses in relation to obesity, diabetes, heart disease and cancer. Br. J. Nutr., 2012, 108, S1-S2.

13. Djordjevic T.M., Šiler-Marinkovic S.S., Dimitrijevic-Brankovic S.I., Antioxidant activity and total phenolic content in some cereals and legumes. Int. J. Food Prop., 2011, 14, 175-184. 
14. Gallegos-Infante J.A., Rocha-Guzman N.E., Gonzalez-Laredo R.F., Ochoa-Martinez L.A., Corzo N., Bello-Perez L.A., Medina-Torres L., Peralta-Alvarez L.E., Quality of spaghetti pasta containing Mexican common bean flour (Phaseolus vulgaris L.). Food Chem., 2010, 11, 1544-1549.

15. Gulewicz P., Martinez-Villaluenga C., Kasprowicz-Potocka M., Frias J., Non-nutritive compounds in Fabaceae family seeds and the improvement of their nutritional quality by traditional processing - a review. Pol. J. Food Nutr. Sci., 2014, 64, 75-89.

16. Hayat I., Ahmad A., Masud T., Ahmed A., Bashir S., Nutritional and health perspectives of beans (Phaseolus vulgaris L.): an overview. Crit. Rev. Food Sci. Nutr., 2014, 54, 580-92.

17. Karamać M., Amarowicz R., Weidner S., Shahidi F., Antioxidant activity of phenolic fractions of white bean (Phaseolus vulgaris L.). J. Food Lipids, 2004, 11, 165-177.

18. Karamać M., Biskup I., Kulczyk A., Fractionation of buckwheat seed phenolics and analysis of their antioxidant activity. Pol. J. Food Nutr. Sci., 2015, 65, 243-249.

19. Luthria D.L., Pastor-Corrales M.A., Phenolic acids content of fifteen dry edible bean (Phaseolus vulgaris L.) varieties. J. Food Compos. Anal., 2006, 19, 205-211.

20. Madhujith T., Naczk M., Shahidi F., Antioxidant activity of common beans (Phaseolus vulgaris L.). J. Food Lipids, 2004, 11, 220-233.

21. Madhujith T., Shahidi F., Antioxidant potential of pea beans (Phaseolus vulgaris L.). J. Food Sci., 2005, 70, S85-S90.

22. Marathe S.A., Rajalakshmi V., Jamdar S.N., Sharma A., Comparative study on antioxidant activity of different varieties of commonly consumed legumes in India. Food Chem. Toxicol., 2011, 49, 2005-2012.

23. Miller H.E., A simplified method for evaluation of antioxidant. J. Am. Oil Chem. Soc., 1971, 45, 91.

24. Moreno-Jiménez M.R.,Cervantes-Cardoza V., Gallegos-Infante J.A., González-Laredo R.F., Estrella I., García-Gasca T.D.J., Herrera-Carrera E., Díaz-Rivas J.O., Rocha-Guzmán N.E., Phenolic composition changes of processed common beans: Their antioxidant and anti-inflammatory effects in intestinal cancer cells. Food Res. Int., 2015, 76, 79-85.

25. Oomah B.D., Cardador-Martinez A., Loarca-Piña G., Phenolics and antioxidative activities in common beans (Phaseolus vulgaris L.). J. Sci. Food Agric., 2005, 85, 935-942.

26. Orak H.H., Karamać M., Amarowicz R., Antioxidant activity of phenolic compounds of red bean (Phaseolus vulgaris L.). Oxid. Commun., 2015, 38, 67-76.

27. Prior R.L., Wu X.L., Schaich K., Standardized methods for the determination of antioxidant capacity and phenolics in foods and dietary supplements. J. Agric. Food Chem., 2005, 53, 4290-4302.

28. Ramirez-Jiménez A.K., Reynoso-Camacho R., Mendoza-Díaz S., Loarca-Piña G., Functional and technological potential of dehydrated Phaseolus vulgaris L. flours. Food Chem., 2014, 161, 254-260.

29. Re R., Pellegrini N.,Proteggente A., Pannala A., Yang M., Rice-Evans C., Antioxidant activity applying an improved ABTS radical cation decolorization assay. Free Rad. Biol. Med., 1999, 26, 1231-1237.

30. Ross K.A., Beta T., Arntfield S.D., A comparative study on the phenolic acids identified and quantified in dry beans using HPLC as affected by different extraction and hydrolysis methods. Food Chem., 2009, 113, 336-344.

31. Singh S.P., Production and utilization. 1999, in: Common Bean Improvement in the Twenty-First Century (ed. S. Singh). Kluwer, Dordrecht, The Netherlands, pp. 1-24.

32. Suárez-Martínez S.E., Ferriz-Martínez R.A., Campos-Vega R., Elton-Puente J.E., de la Torre-Carbot K., García-Gasca T., Bean seeds: leading nutraceutical source for human health. CyTA-J. Food, 2016, 14, 131-137.

33. Xu B.J., Yuan S.H., Chang S.K.C., Comparative analyses of phenolic composition, antioxidant capacity, and color of cool season legumes and other selected food legumes. J. Food Sci., 2007, 72, S167-S177.

Submitted: 22 March 2016. Revised: 28 April 2016. Accepted: 9 May 2016. Published on-line: 12 July 2016. 